\title{
Effect of D ala2 metenkephalinamide on feline jejunal and ileal water and electrolyte transport
}

\author{
M Descroix-Vagne*, C Caillet ${ }^{\star *}$, G Charpin, AR Chikhlssa ${ }^{\star \star *}$,

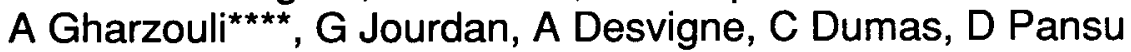

INSERM U 45, Unité de Physiopathologie Digestive, pavillon Hbis, hôpital Edouard Herriot, 69437 Lyon Cedex 03, France

(Received 5 May 1990; accepted 29 August 1990)

\begin{abstract}
Summary - The aim of this investigation was to compare the effect of an opioid, $\mathrm{D}$ ala $\mathrm{a}_{2}$ metenkephalinamide (DAMA), on net jejunal and ileal water and electrolyte fluxes using the gut perfusion technique in the anesthetized cat. Intestinal transport was measured during intravenous infusion of serial doses of 2,6 , and $18 \mu \mathrm{g}^{\circ} \mathrm{kg}^{-1} \cdot \mathrm{h}^{-1}$ of DAMA in 6 cats. Each cat was its own control during an intravenous infusion of $150 \mathrm{mmol} / \mathrm{NaCl}$ preceding the first dose of peptide and following the last dose of DAMA. Both jejunal and ileal segments were isolated by inflated balloons and were studied at the same time. Fifteen $\mathrm{ml}$ of an iso-osmolar test solution with hypo-osmolar ion contents and complementary mannitol were administered in the uptstream tube and collected $1 \mathrm{~h}$ later in the downstream tube. In the jejunum, water secretion was dose-dependentiy reversed to an absorption from a control value of $+0.5 \pm 0.4$ to $-0.83 \pm 0.5 \mathrm{ml}^{-1} \mathrm{~h}^{-1} \cdot 10 \mathrm{~cm}^{-1}$; in the ileum, water absorption was increased from $-0.5 \pm 0.3$ to $-1.5 \pm 0.2 \mathrm{ml} \cdot \mathrm{h}^{-1} .10 \mathrm{~cm}^{-1}$. The net absorption of all electrolytes, ie sodium, chloride, bicarbonate, potassium and calcium also increased during peptide administration. However, a qualitative difference in the ion transport was observed between the jejunum and the ileum.
\end{abstract}

absorption / cat / enkephalin / electrolyte flux / intestine / luminal perfusion

Résumé - Effet de la D Ala2 métenképhalinamide sur le transport d'eau et des électrolytes au niveau du jéjunum et de l'iléon chez le chat. Le but de ce travail a été de comparer l'effet d'un opiacé, la $\mathrm{D} \mathrm{Ala}_{2}$ métenképhalinamide (DAMA), sur les flux d'eau et d'électrolytes à 2 niveaux intestinaux, le jéjunum et l'iléon, en utilisant une technique modifiée de perfusion intestinale chez le chat anesthésié. Les transports intestinaux ont été mesurés pendant une perfusion intraveineuse continue de doses croissantes de DAMA de 2, 6 et $18 \mu \mathrm{g}^{\circ} \mathrm{kg}^{-1} \cdot \mathrm{h}^{-1}$, chez 6 chats. Chaque chat a été son propre témoin pendant une perfusion intraveineuse de chlorure de sodium 0,15 mol.t-1 précédant la première dose et suivant la dernière dose de DAMA. Chacun des 2 segments intestinaux a été délimité par 2 sondes à ballonet. Quinze $\mathrm{ml}$ d'une solution iso-osmolaire renfermant du mannitol pour compenser une hypo-osmolarité ionique ont été administrés dans la sonde en amont du segment. Le contenu du segment a été recueilli par la sonde située en aval, après une heure in situ. Dans le jéjunum, la sécrétion d'eau observée en période basale $\left(+0.5 \pm 0.4 \mathrm{ml} \cdot \mathrm{r}^{-1} \cdot 10 \mathrm{~cm}^{-1}\right)$ a été remplacée

* Correspondence and reprints. ** Present address: Institut Merieux, 69260 Marcy l'Étoile, Charbonnières-les-Bains, France. ${ }^{* * *}$ Present address: University of Damascus, Laboratory of Physiology, Faculty of Medicine, Damascus, Syria. ${ }^{* * * *}$ Present address: Institut de Biologie, Université de Sétif, 19000 Algérie.

Part of this study has appeared in abstract form (Gastroenterology (1989), 96, 521A 
par une absorption $\left(-0.83 \pm 0.5 \mathrm{~m} / . \mathrm{t}^{-1} \cdot 10 \mathrm{~cm}^{-1}\right)$. Dans l'iléon, l'absorption hydrique obtenue en période basale $\left(-0.5 \pm 0.3 \mathrm{~m} / \cdot \mathrm{h}^{-1} \cdot 10 \mathrm{~cm}^{-1}\right)$ a été augmentée $\left(-1.5 \pm 0.2 \mathrm{~m} / \cdot \mathrm{h}^{-1} \cdot 10 \mathrm{~cm}-1\right)$. L'absorption nette de tous les électrolytes, sodium, chlorure, bicarbonate, potassium et calcium a été augmentée pendant l'administration de DAMA. Cependant, une différence qualitative du transport ionique a été observée entre le jéjunum et l'iléon.

absorption / chat / enképhaline / électrolytes / flux / intestin / perfusion luminale

\section{INTRODUCTION}

The intestinal mucosa is innervated by cholinergic, adrenergic, peptidergic and intrinsic amine-handling nerve fibers (Furness and Costa, 1980; Thomas and Templeton, 1981). Both parasympathetic (Morris and Turnberg, 1980) and sympathetic (Morris and Turnberg, 1981) autonomic pathways have been implicated in the physiological control of intestinal transport. Stimulation of sympathetic nerves has resulted in a 2-fold increase in water absorption in the cat small intestine (Brunsson et al, 1979), while parasympathetic pathways are involved in intestinal secretion (Morris and Turnberg, 1980). Enkephalins are naturally occurring peptides (Polak et al, 1977) which are present in the enteric nervous system, located in extrinsic nerves, in cells and fibers of the myenteric plexus. They have an affinity for delta and mu opiate receptors (Bradbury et al, 1976; Lord et al, 1977), which are present in myenteric and submucosal plexus in gastro-intestinal smooth muscle (Furness and Costa, 1980) but not on enterocytes (Binder et al, 1984) in rats. There is evidence that opiates and enkephalins exert a large spectrum of effects in the digestive tract (Olson et al, 1987); in particular, they inhibit intestinal secretion and increase intestinal absorption. The antisecretory effect has been demonstrated in vivo either on basal jejunal secretion in the dog (Barbezat and Reasbeck, 1983) or in the rat (Fogel and Kaplan, 1984), or on cholera toxin, prostaglandin E1 and VIP-induced secretion in the rat (Beubler and Lembeck, 1979; Coupar, 1983). The absorptive effect has been showed principally in vitro at the ileal level in the rabbit (Dobbins et al, 1980; McKay et al, 1981) and the guineapig (Kachur et al, 1980), as a decrease of short-circuit current and an increase in net $\mathrm{NaCl}$ absorption.

The aim of this experiment was to study the effect of enkephalin on water and electrolyte transport in the cat in which the action of opioid peptides has not been studied. The hydroelectrolytic transport was studied simultaneously in the jejunum and the ileum of the same animal. The cats were kept anesthetized for several days, to repeat such a comparison, using a technique (Vagne et al, 1986) derived from the gut perfusion technique (Barbezat and Reasbeck, 1983). The well-known inhibitory effect of enkephalins on motility in the cat as in other species (Edin et al, 1980) was overcome by the complete recovery of the intestinal segment contents, at the end of each hour, based on marker recovery

\section{MATERIALS AND METHODS}

\section{Animals}

Studies were performed in 6 cats (purchased from Iffa-Credo, BP 109, 69210 l'Arbresle, France) which were anesthetized iv with pentobarbital $\left(25 \mathrm{mg} \cdot \mathrm{kg}^{-1}\right)$. After a median incision of the abdomen, a balloon-equipped tube (armou- 
red tracheal tube, ch 18, Rüsch, FRG) was inserted into the jejunum just beneath Treitz'ligament, through a small incision and attached with a purse-shaped surgical ligation; a second identical tube was placed $\approx 30 \mathrm{~cm}$ below in the opposite position so that when the balloons were inflated a loop of about $30 \mathrm{~cm}$ was delimited. The exact length was determined at the completion of the study. In the same way, a tube was placed at the end of the ileum and a second tube was placed upstream in the opposite position. Between the 2 limited segments a catheter was inserted and connected to a syringe filled with ethchlorvinol (Placidyl, Abbott). The luminal instillation of $0.2-0.3 \mathrm{ml} / \mathrm{d}$ permitted a long-lasting hypnosis (Vagne et al, 1986). A gastric cannula was inserted in the gastric fundus and brought to the outside through an incision in the abdominal wall (fig 1). The animals were kept in a ventilated incubator at $30^{\circ} \mathrm{C}$ with $50 \%$ humidity and ventilation. Each day, the animals were weight-controled and received penicillin, glucose and saline by subcutaneous route as described previously (Vagne et al, 1986).

\section{Experimental design}

Each day, the 4 balloons were inflated with 10 $\mathrm{ml}$ of air and the delimited jejunal and ileal loops were rinsed with warmed distilled water which was drained into the distal tubes. Some air was pushed into the loop to get rid of the water. The loops were then washed with $20 \mathrm{ml}$ of water containing $30 \mathrm{mg} / \mathrm{l}$ of phenol red (PR). PR acted as a marker for the water left in the loop after pushing some air through and before administering $15 \mathrm{ml}$ of the test solution. The solution contained $70 \mathrm{mM}$ of $\mathrm{NaCl}, 10 \mathrm{mM}$ of $\mathrm{NaHCO}_{3}$, $5.2 \mathrm{mmol} / \mathrm{I}^{-1}$ of KCl, $1.2 \mathrm{mmol} \cdot \mathrm{I}^{-1}$ of $\mathrm{CaCl}_{2}, 136$ mmolet-1 of mannitol. ${ }^{14} \mathrm{C}$ Polyethylene glycol 4 000 (PEG) (NEN, France) mixed with $5 \mathrm{~g}^{\circ-1}$ of cold PEG 4000 (PEG) (NEN, France) mixed with $5 \mathrm{~g}^{-1}$ of cold PEG 4000 was used as a non-absorbable marker $(3.7 \mathrm{kBq} / \mathrm{ml})$. The test solution was drained after $1 \mathrm{~h}$ and completely recovered by washing with $20 \mathrm{ml}$ of water containing phenol red as a marker $(30 \mathrm{mg} / \mathrm{l})$. The same test was repeated 6 times per day, with a lag time of $10 \mathrm{~min}$ between 2 tests. The first 2 tests were given during saline intravenous administration, the next 3 tests during intravenous administration of serial doses of DAMA of 2, 6 and $18 \mu \mathrm{g} / \mathrm{kg}$ per $\mathrm{h}$, and the last test during saline iv again. The tests for the jejunum and for the ileum were separated by 5 -min intervals.

\section{Drugs}

D Ala $_{2}$ metenkephalinamide was purchased from Sigma Chemicals, France.

\section{Laboratory analysis}

${ }^{14} \mathrm{C}$ PEG activity was determined by liquid scitillimetry with an external standard to correct for quenching, in the test solution, in the recovered solution and in the phenol red washing solution. Radioactivity was corrected for interference with the amount of phenol red present in the solution according to a determined linear relationship. Only the experiments where the recovery of labeled PEG was $80 \%$ or more were analyzed.

Phenol red was measured at $\mathrm{pH} 10.5$ using an automated technique (Auto-analyzer, Technicon) and a spectrophotometric measurement at $560 \mathrm{~nm}$ (Beckman DB). Osmolality was measured by depression of freezing point using a Fiske osmometer.

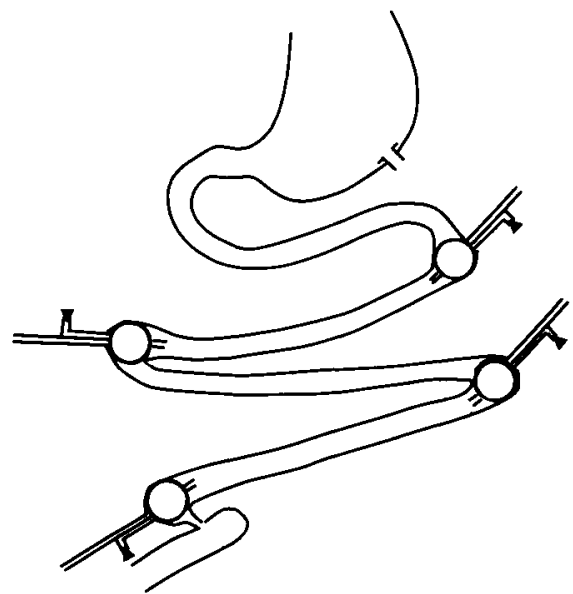

Fig 1. Position of the 4 tubes with their balloons inflated showing the delimitation of the jejunal and ileal segments. A gastric cannula was inserted to remove gastric juice and reflux biliary secretion. 
$\mathrm{Na}, \mathrm{Ca}$ and $\mathrm{K}$ contents were determined by flame photometry. $\mathrm{Cl}$ was measured by potentiometric titration. Bicarbonate concentration was determined by acid back-titration using an automatic titrator (Radiometer) (Vagne et al, 1986).

\section{Calculations}

$V t=$ volume of test solution injected into the intestine (15 ml)

$C t A=$ concentration of ${ }^{14} \mathrm{C} P E G$ in the test solution.

$C t E=$ concentration in each electrolyte in the test solution.

$V r=$ volume of washing phenol red containing water $(20 \mathrm{ml})$

$\mathrm{Cr}=$ concentration of phenol red in the washing solution

$V s=$ volume recovered after $1 \mathrm{~h}$ from the intestine

CsA = concentration of ${ }^{14} \mathrm{C} P E G$

CsR $=$ concentration of phenol red

CsE $=$ concentration of each electrolyte

$V w=$ volume of washing water recovered

CWA $=$ concentration of ${ }^{14} \mathrm{C} P E G$

$C w R=$ concentration of phenol red

Net flux was calculated as the difference between the recovered and the administered amounts for volume and ions.

\section{For volume}

The $15 \mathrm{ml}$ of test solution (Vt) administered were corrected to give the exact initial volume (Vi) as the volume corresponding to the amount of ${ }^{14} \mathrm{C}$ PEG recovered in the test solution and in the washing solutions:

$V i=(V s \times C s A) / C t A+(V W \times C w A) / C t A$

The volume of test solution recovered (Vs) was corrected to give the exact final volume (Vf) by adding the amount of the test solution left in the washing solution ( ${ }^{14} \mathrm{C}$ PEG) and by substracting the volume of washing solution remaining from the preceding washing (phenol red).
$V f=V s+[(V w \times C w A) / C s A]-[(V s \times C s A) /$ $\mathrm{CtR}]$

The water net flux was equal to : $V f-V i$, expressed in $\mathrm{ml}^{\mathrm{h}} \mathrm{h}^{-1}$ and given per $10 \mathrm{~cm}$ of intestine.

Net water absorption from the lumen was then expressed as a negative value and net secretion into the lumen as a positive value.

\section{For electrolytes}

The initial amount administered was:

Vix CtE

- the recovered amount was:

$V f o \times C s E$

$V f e=V s+[(V w \times C w A) / C s A]$

The electrolyte net flux was equal to $=(V f e \times$ CsE $-\left(\right.$ Vi $\times$ CtE), expressed in $\mu \mathrm{Eq}^{\circ} \mathrm{h}^{-1}$ and is given per $10 \mathrm{~cm}$ of intestine. Positive value indicates a secretion, negative value an absorption.

\section{Statistical analysis}

The comparison of the data obtained from the same animal during basal state and during DAMA administration was calculated by Student's $t$-test for paired small samples values. As too small a sample size might fail to detect that the distribution differed from the approximately normal distribution, the Mann-Whitney U-test was also systematically calculated. The variation was considered as statistically significant when both statistical tests were significant $(P<$ 0.05).

\section{Histological control}

The animals were sacrificed after $4 \mathrm{~d}$. The lengths of jejunum and ileum delimited by the 2 balloons were measured. Fragments were submitted to histological control. Jejunal and ileal mucosae were not significantly altered after $4 \mathrm{~d}$ of intestinal perfusion.

Two cats were surgically relieved of their tubes and gastric cannula and were allowed to recover with appropriate medical care. They were kept in the laboratory for several months 
after the test period in excellent condition. The recovery indicates that no irreversible change was induced during the experiments. They are now living peacefully in a friendly veterinarian family.

\section{RESULTS}

In basal conditions, the jejunum secreted water, $\mathrm{Na}^{+}(P<0.01), \mathrm{Cl}^{-}(P<0.01), \mathrm{K}^{+}$ and $\mathrm{Ca}^{2+}$, and slightly absorbed bicarbonate. In contrast, the ileum absorbed water and $\mathrm{Cl}^{-}$and secreted $\mathrm{Na}^{+}$and bicarbonate
$(P<0.001)$ with $\mathrm{K}^{+}$and $\mathrm{Ca}^{2+}(P<0.02)$ (fig 2). The next flux of bicarbonate and $\mathrm{Cl}^{-}$ were different in the jejunum and the ileum ( $t$-test for paired values respectively 4.51 , $P<0.01$ and $3.09, P<0.02$ ).

The electrolyte concentration of the jejunal contents did not differ statistically from that of the test solution, except for bicarbonate concentration which was lower. Bicarbonate concentration was increased in the ileal contents while $\mathrm{Cl}^{-}$concentration was lowered by the same amount without any change in $\mathrm{Na}^{+}$concentration (table l).

Table I. Electrolyte concentraticns after $1 \mathrm{~h}$.

\begin{tabular}{|c|c|c|c|c|c|c|}
\hline \multirow[b]{2}{*}{$\mathrm{mmol} / \mathrm{l}$} & \multicolumn{3}{|c|}{ Jejunum } & \multicolumn{3}{|c|}{ Ileum } \\
\hline & $\begin{array}{c}\text { Test } \\
\text { solution }\end{array}$ & Basal & $\begin{array}{c}\text { DAMA } \\
(18 \mu g / \mathrm{kg} \cdot \mathrm{h})\end{array}$ & $\begin{array}{l}\text { Test } \\
\text { solution }\end{array}$ & Basal & $\begin{array}{c}\text { DAMA } \\
(18 \mu \mathrm{g} / \mathrm{kg} \cdot \mathrm{h})\end{array}$ \\
\hline $\begin{array}{l}{\left[\mathrm{Na}^{+}\right]} \\
\text {Mean } \\
\text { SEM }\end{array}$ & 80 & $\begin{array}{c}86 \\
4\end{array}$ & $\begin{array}{c}74^{*} \\
4\end{array}$ & 80 & $\begin{array}{r}80 \\
6\end{array}$ & $\begin{array}{c}60^{*} \\
6\end{array}$ \\
\hline $\begin{array}{l}{[\mathrm{CL}-]} \\
\text { Mean } \\
\text { SEM }\end{array}$ & 78 & $\begin{array}{r}83 \\
4\end{array}$ & $\begin{array}{c}73^{*} \\
3\end{array}$ & 78 & $\begin{array}{c}62^{*} \\
6\end{array}$ & $\begin{array}{c}44^{*} \\
6\end{array}$ \\
\hline $\begin{array}{l}{\left[\mathrm{K}^{+}\right]} \\
\text {Mean } \\
\text { SEM }\end{array}$ & 5.2 & $\begin{array}{l}5.1 \\
0.2\end{array}$ & $\begin{array}{l}4.9 \\
0.4\end{array}$ & 5.2 & $\begin{array}{l}5.1 \\
0.4\end{array}$ & $\begin{array}{l}4.4 \\
0.3\end{array}$ \\
\hline $\begin{array}{l}{\left[\mathrm{Ca}^{2+}\right]} \\
\text { Mean } \\
\text { SEM }\end{array}$ & 1.2 & $\begin{array}{l}1.03 \\
0.08\end{array}$ & $\begin{array}{l}0.99 \\
0.08\end{array}$ & 1.2 & $\begin{array}{l}1.34 \\
0.05\end{array}$ & $\begin{array}{l}1.27 \\
0.06\end{array}$ \\
\hline $\begin{array}{l}{\left[\mathrm{HCO}_{3}^{-}\right]} \\
\text {Mean } \\
\text { SEM }\end{array}$ & 10 & $\begin{array}{l}5.9^{\star} \\
1.4\end{array}$ & $\begin{array}{l}3.7 \\
1\end{array}$ & 10 & $\begin{array}{c}21.5^{\star *} \\
2.8\end{array}$ & $\begin{array}{r}15.3 \\
2.4\end{array}$ \\
\hline $\begin{array}{l}\text { mOsm } \\
\text { Osmolar } \\
\text { Mean } \\
\text { SEM }\end{array}$ & $\begin{array}{r}329.2 \\
3.1\end{array}$ & $\begin{array}{r}322 \\
5.7\end{array}$ & $\begin{array}{c}317^{\star *} \\
6\end{array}$ & $\begin{array}{r}330.2 \\
3.2\end{array}$ & $\begin{array}{r}317 \\
7.9\end{array}$ & $\begin{array}{c}306.6^{*} \\
6.8\end{array}$ \\
\hline
\end{tabular}

Comparison with the preceding column; $t$-test for paired values and small samples; ${ }^{*}=P<0.05,{ }^{* *}=P<0.01 ; N=$ 9 experiments in 7 cats. 


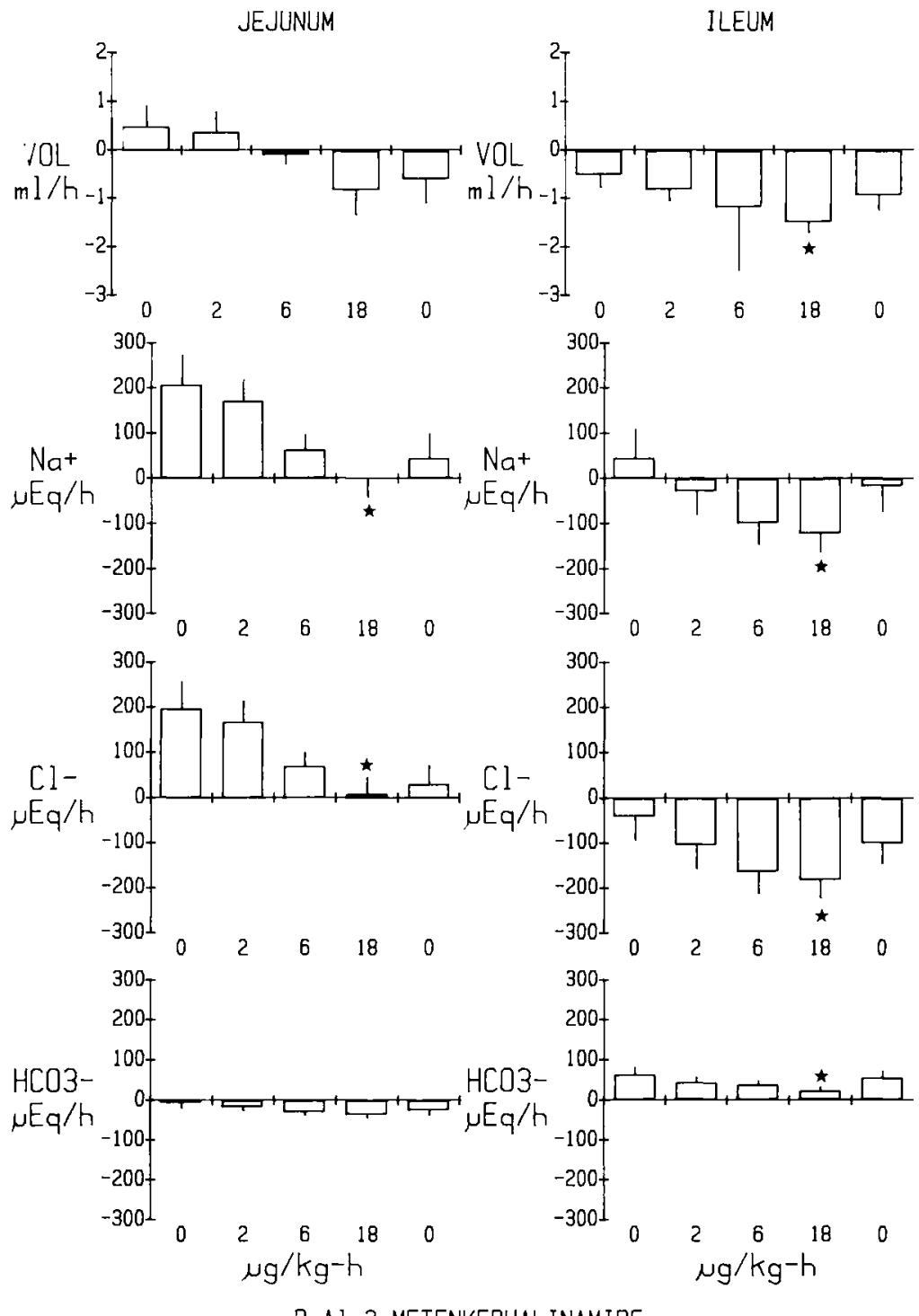

I Ala2 METENKEPHAL INAMIDE

Fig 2. Net fluxes (per $\mathrm{h}$ and per $10 \mathrm{~cm}$ of intestine) of water, $\mathrm{Na}^{+}, \mathrm{Cl}^{-}, \mathrm{HCO}^{-}$from the lumen of jejunum (left) and ileum (right), during intravenous saline infusion (0), D ala2 metenkephalinamide $(2,6$ and $18 \mu \mathrm{g}^{\circ} \mathrm{kg}^{-1} \cdot \mathrm{h}^{-1}$ ), and saline infusion again (0). Net secretion has positive value and net absorption negative value. The histograms represent the mean of 9 experiments in 6 cats and the vertical bars are the SEM. The star indicates a statistical difference $(P<0.05)$ between the value and the saline value taken as control. 


\section{The continuous $I V$ infusion of DAMA}

It resulted in a change from jejunal water secretion to water absorption (from $0.5 \pm$ 0.4 to $-0.8 \pm 0.5 \mathrm{ml} / \mathrm{h}$ ) and in an increase of ileal water absorption $(P<0.05)$ (from $0.5 \pm 0.3$ to $-1.5 \pm 0.2 \mathrm{ml} / \mathrm{h}$ ). The changes were related to the dose of DAMA and in our experimental design the dose of 18 $\mu \mathrm{g} \cdot \mathrm{kg}^{-1} \cdot \mathrm{h}^{-1}$ was the most efficient dose for all the effects which were determined. Jejunal $\mathrm{Na}^{+}$and $\mathrm{Cl}^{+}$secretions were decreased (respectively from $208 \pm 5$ to $-3 \pm 38$ and $197 \pm 59$ to $9 \pm 35 \mu \mathrm{Eq} / \mathrm{h}$ ) while ileal $\mathrm{Na}$ secretion was replaced by an absorption (from $46 \pm 62$ to $-122 \pm 39 \mu \mathrm{Eq} / \mathrm{h}$ ) and $\mathrm{Cl}$ - absorption was increased (from $-42 \pm$ 53 to $-184 \pm 39 \mu \mathrm{Eq} / \mathrm{h}),(P<0.05)$, (fig 2$)$.

For bicarbonate, the increase in jejunal absorption was not statistically significant but the decrease in ileal bicarbonate secretion was significant $(P<0.05)$ (from $64 \pm$ 15 to $23 \pm 8 \mu \mathrm{Eg} / \mathrm{h}$ ). Both $\mathrm{K}^{+}$and $\mathrm{Ca}^{2+}$ secretions from jejunum and ileum were decreased with a significant change, leading to absorption in the ileum only for $\mathrm{K}^{+}$(from $1.6 \pm 4$ to $-6.1 \pm 1.7 \mu \mathrm{Eq} / \mathrm{h}$ ) and in the jejunum for $\mathrm{Ca}^{2+}$ (from $0.48 \pm 0.77$ to -0.87 $\pm 0.66 \mu \mathrm{mol} / \mathrm{h}$ ).

During peptide administration, $\mathrm{Na}^{+}$and $\mathrm{Cl}$ - concentrations of the jejunal contents collected after $1 \mathrm{~h}$ were decreased $(P<$ $0.05)$. Bicarbonate concentration was decreased (table I).

$\mathrm{Na}^{+}$and $\mathrm{Cl}^{-}$concentrations of the ileal contents were decreased $(P<0.05,0.02)$. Bicarbonate concentration decrease was at the limit of significance. A significant decrease in osmolarity was observed in both jejunal and ileal contents $(P<0.05)$ (table I).

\section{The return to basal conditions}

During the replacement of DAMA perfusion by saline resulted in a more or less com- plete return to basal water and ion transport (fig 2). Electrolyte concentrations in the jejunum as well as in the ileum returned to near basal levels.

\section{DISCUSSION}

We have studied simultaneously in the same cat water and electrolyte transport in the jejunum and in the ileum in basal conditions and in response to DAMA intravenous infusion.

We determined in preliminary experiments the low concentration of sodium and chloride solution which would be suitable for approaching the zero flux ion concentration in both segments (Fromm and Hegel, 1987) in order to amplify an effect on absorption. Using an iso-osmolar test solution containing $80 \mathrm{mM} \mathrm{Na}$ and 78 mmol $\|^{-1} \mathrm{Cl}$, we induced, in basal conditions, in the jejunum, a slight water and ion secretion including $\mathrm{Na}, \mathrm{Cl}, \mathrm{K}$ and $\mathrm{Ca}$. Only bicarbonate was slightly absorbed. In the ileum, we induced a slight absorption of water and $\mathrm{Cl}$ and a secretion of bicarbonate, $\mathrm{Na}, \mathrm{K}$ and $\mathrm{Ca}$. The jejunal net fluxes of bicarbonate and $\mathrm{Cl}$ statistically differed from the ileal ones. The difference in the mechanism of ion exchanges in both segments was objectified by the difference in final concentrations. In the jejunum, a significant decrease of bicarbonate concentration was observed without any change in $\mathrm{Cl}$ concentration, while in the ileum the increase of bicarbonate concentration was associated with a decrease in $\mathrm{Cl}$ concentration of the same magnitude. The variation obtained in the ileum was compatible with $\mathrm{HCO}_{3} / \mathrm{Cl}$ exchange, inducing the chloride absorption against the chemical gradient.

We showed that DAMA induced an increase in water and electrolyte absorption in both jejunum and ileum. This effect was 
secondary to a decrease in secretion of water, $\mathrm{Na}$ and $\mathrm{Cl}$ in the jejunum. In the ileum, DAMA induced an increase in the absorption of water $\mathrm{Na}$ and $\mathrm{Cl}$ and a decrease in bicarbonate secretion. For both intestinal segments, the effect of DAMA was dose-dependent and the dose of 18 $\mu \mathrm{g} \cdot \mathrm{kg}^{-1} \cdot \mathrm{h}^{-1}$ was the most efficient. The decrease in $\mathrm{Na}$ and $\mathrm{Cl}$ concentrations and in osmolarity in the solution after 1 hour of DAMA infusion showed that more ions than water were absorbed in the jejunum as well as in the ileum. In both intestinal segments the induction of absorption was realized against the chemical gradient. The lack of change of $\mathrm{K}$ and $\mathrm{Ca}$ concentration suggests that their transport was only related to water movement.

An increase in water and ion absorption has been demonstrated following serosal administration of enkephalin in vitro in the rabbit ileum (Dobbins et al, 1980) and in the guinea pig (Kachur et al, 1980), in vivo in the dog (Barbezat and Reasbeck, 1983) and the rat (Fogel and Kaplan, 1984) jejunum. Doses used in the dog $\left(20 \mu \mathrm{g}^{\circ} \mathrm{kg}^{-}\right.$ $1 \cdot \mathrm{h}^{-1}$ ) were similar to those used in the cat, and the decrease of ionic concentration of the fluid after absorption was also observed (Barbezat and Reasbeck, 1983).

The in vitro effect of DAMA, studied on ileal tissue, has been shown to be associated with a decrease in the short-circuit current (Dobbins et al, 1980; McKay et al, 1981; Binder et al, 1984), suggesting an increase in electrogenic chloride absorption (Dobbins et al, 1980; McKay et al, 1981). Sodium changes were a little at variance with some studies reporting no change (McKay et al, 1981) and others showing an increased absorption (Dobbins et al, 1980) during exposure to enkephalins. In vivo studies (Barbezat and Reasbeck, 1983) revealed a more pronounced increase in net absorption of sodium and bicarbonate during enkephalin infusion in dog than in cat or rat (Coupar, 1978). Our protocol provides information on the attained equilibrium, as opposed to experiments exploring the difference of potential induced by the electrogenic transport. However, we were unable to demonstrate any change in the cation-anion ratio. In basal conditions, the luminal solution collected after $1 \mathrm{~h}$ contained more cations than anions (delta in the jejunum and ileum, respectively $26 \pm 10$ and $28 \pm 8 \mu \mathrm{mol} / \mathrm{h}$ ). During DAMA stimulation a difference of the same magnitude was observed (delta in the jejunum and the ileum respectively 35 \pm 13 and $31 \pm 12 \mu \mathrm{mol} / \mathrm{h})$. This cationanion difference could be consecutive to the secretion of unidentified anion(s) that we did not determine. The same cationanion difference was observed for the jejunum and the ileum.

Our results indicate that DAMA is effective in the cat, as in other species (Cooke, 1986), at 2 different levels of the intestine, jejunum and ileum, even though it is clearly evident that the mechanisms of ion transport differ. A different motility response to metenkephalin was also observed at the 3 levels of the small intestine in the cat (Radomirov et al, 1990). This confirms that intestinal transport is controlled by several neurotransmitters and that opioids intervene in cat as in other species in increasing absorption. Our protocol excludes the possibility that this effect could be due to motility inhibition, which is a wellknown property of the opioid peptides (Rozé and Dubrasquet, 1983) and which has traditionally been thought to underlie their antidiarrheal or constipating activity (Manara and Bianchetti, 1985). Previous work has shown that mucosal blood flow can influence absorption (Mailman, 1984), a factor which has not been studied in our experiments. Since no enkephallin receptors have been discovered on dog mucosal cells but in membranes of myenteric and 
deep muscular plexus (Allescher et al, 1989), it has been proposed that enkaphalin (which reduces acetylcholine release at muscle level: Paton, 1957), induces absorption by adrenergic preponderance (Taper, 1983) of the balance of adrenergic and cholinergic control of intestinal transport. But local non-cholinergic, non adrenergic pathways, like peptidergic release, might be involved too. Our data show that our model is convenient for studying the direct effect of drugs on intestinal absorption independent of intestinal motility.

\section{ACKNOWLEDGMENT}

We are grateful to MJ Carew for reviewing the English manuscript.

\section{REFERENCES}

Allescher HD, Sultan Ahmad, Kostka P, Kwan CY, Daniel EE (1989) Distribution of opioid receptors in canine small intestine: implication for function. Am J Physiol 19, G966G974

Barbezat GO, Reasbeck PG (1983) Effect of bombesin, calcitonin and enkephalin on canine jejunal water and electrolyte transport. Dig Dis Sci 28, 273-277

Beubler E, Lembeck F (1979) Inhibition of stimulated fluid secretion in the rat small and large intestine by opiate agonists. NaunynSchmiedebergs Arch Pharmacol 306, 113118

Binder HJ, Laurenson JP, Dobbins JW (1984) Role of opiate receptors in regulation of enkephalin stimulation of active sodium and chloride absorption. Am J Physiol 247, G432G436

Bradbury AF, Smyth DG, Snell CR, Birdsall NJM, Hulme EC (1976) C fragment of lipotropin has a high affinity for brain opiate receptors. Nature 260, 793-795

Brunsson I, Eckland $S$, Jodal $M$, Lundgren $O$, Sjovall $H$ (1979) The effect of vasodilation and sympathetic nerve activation on net water absorption in the cat's small intestine. Acta Physiol Scand 106, 61-68

Cooke HJ (1986) Neurobiology of the intestinal mucosa. Gastroenterology 90, 1057-1081

Coupar IM (1978) Inhibition by morphine of prostaglandin stimulated fluid secretion in rat jejunum. Br J Pharmacol 63, 57-63

Coupar IM (1983) Characterization of opiate receptor population mediating inhibition of VIPinduced secretion from the small intestine of the rat. Br J Pharmaco/ 80, 371-376

Dobbins J, Racusen L, Binder HJ (1980) Effect of $D$-alanine methionine enkephalin amide on ion transport in rabbit ileum. $J$ Clin Invest 66 , 19-28

Edin R, Lundberg J, Terenius L, Dahlstrom A, Hikfelt T, Kewenter J, AhIman H (1980) Evidence for vagal enkephalinergic neural control of the feline pylorus and stomach. Gastroenterology 78, 492-497

Fogel R, Kaplan RB (1984) Role of enkephalins in regulation of basal intestinal water and ion absorption in the rat. Am J Physiol 246, G386-G392

Fromm M, Hegel U (1987) Net ion fluxes and zero flux limiting concentrations in rat upper colon and rectum during anesthesia-induced aldosterone liberation. Pflügers Arch 408, 185-193

Furness JB, Costa M (1980) Type of nerves in the enteric nervous system. Neurosci 5, 1-20

Kachur JF, Miller RJ, Field M (1980) Control of guinea-pig intestinal electrolyte secretion by delta-opiate receptor. Proc Natt Acad Sci USA 77, 2753-2756

Lord JAH, Waterfield AA, Hughes J, Kosterlitz HW (1977) Endogenous opioid peptides: multiple agonists and receptors. Nature 267, 495-499

Mailman D (1984) Morphine-neural interactions on canine absorption and blood flow. $B r J$ Pharmacol 81, 263-270

Manara L, Bianchetti A (1985) The central and peripheral influences of opioids on gastrointestinal propulsion, Annu Rev Pharmacol Toxicol 25, 249-273

McKay JS, Linaker ED, Turnberg LA (1981) Influence of opiates on ion transport accross rabbit ileal mucosa. Gastroenterology 81 , 279-284 
Morris A, Turnberg $L$ (1980) The influence of a parasympathetic agonist and antagonist on human intestinal transport in vivo. Gastroenterology 79, 861-866

Morris A, Turnberg $L$ (1981) Influence of isoproterenol and propranolol on human intestinal transport in vivo. Gastroenterology 81, 10761079

Olson GA, OIson RD, Kastin AJ (1987) Endogenous opiates: 1986. Peptides 8, 1135-1164

Paton W (1957) The action of morphine and related substances on contraction and acetylcholine output of coaxially stimulated guinea pig ileum. Br J Pharmacol 11, 119-127

Polak JM, Bloom SR, Sullivan SN, Facer P: Pearse AGE (1977) Enkephalin-like immunoreactivity in the human gastrointestinal tract. Lancet i, 972-974
Radomirov R, Venkova K, Davidoff M, Pencheva $N(1990)$ Effects of met-enkephalin on the mechanical activity and distribution of metenkephalin-like immunoreactivity in the cat small intestine. Peptides 11, 417-425

Rozé C, Dubrasquet M (1983) Endorphines, enképhalines et tube digestif. Gastroenterol Clin Biol 7, 177-188

Taper E (1983) Local modulation of intestinal ion transport by enteric neurons. Am J Physiol 244, G457-468

Thomas EM, Templeton D (1981) Noradrenergic innervation of the villi of rat jejunum. $J$ Auton Nerv Syst 3, 25-29

Vagne $M$, Roche $C$, Collinet $M$, Desvigne A, Mutt V (1986) An improved technique for studying pancreatic secretion in anesthetized cats. Sci Techn Anim Lab 11, 123-126 